Isles. The report, based on a two years survey by Mr. S. F. Markhan, is accompanied by a short nontechnical pamphlet, "Museums and the Public" for the use of museum committees.

\section{Mycenean Athens}

Tine discovery at Athens of a chamber-tomb of Mycenean age, which presumably had served for a royal burial, corroborates tradition, but at the same time necessitates a new orientation in assessing the importance of the settlement of Attica in early preclassical times. The chamber was brought to light in the course of the present-the ninth-season of excavation on the Acropolis by the American School of Classical Studies. In a preliminary account of the discovery (Illustrated London News, July 22), Prof. T. L. Shear of Princeton University, field-director of the excavation, states that the tomb is situated in shallow accumulations of deposit on the northern slope of the Acropolis. It consists of a rectangular chamber, filled with splintered rock and approached by a dromos, or passage, some $45 \mathrm{ft}$. in length, but which originally may have been longer, as the outer end is cut by the Roman wall. The earth-filling of this passage contained a number of Mycenean potsherds. Both passage and burial chamber had been cut from the rock; and the entrance to the chamber from the passage is through a rock-cut doorway. This doorway was closed by carefully packed stones, which clearly had not been disturbed since they were placed in position.

INSIDE the chamber on one of the rock-cut benches, which run along each side, wero six vases and a cylindrical ivory box in their original position. The vases had been crushed by the collapse of the roof, but the ivory box, which is described as " $\mathrm{a}$ masterpiece of artistic design and of technical execution", was intact. East of tho doorway were two large vases standing on the floor by a copper ladle. The grave was cut in the rock to a depth of four feet. It had been covered by a stone slab; but this had been removed, and Iay diagonnlly by the grave. Neither bones nor offerings were found in the grave, although there was one small disk of gold in the earth and stones which filled the grave. On the floor beside the slab lay a group of small toilet articles-a bronze mirror, a small ivory box, and ivory pins; and north of the grave, also on the floor, were three piles of gold ornaments. The pottery is of a single period and is characteristically Mycenean in form and decoration. Exact parallels can be found in Mycenean pottery from the Argive Heraeum and elsewhere belonging to the third Late Helladic period of the first half of the fourteenth century 3.C. The state in which the tomb was found and the character of the offerings lead Prof. Shear to the conclusion that this is the burial place of a lady, probably belonging to the royal house of Erechtheus, the legendary king of Athens, whose body was removed when the roof of the chamber collapsed; while the wealth of the offerings-overlooked when the body was removedgives rise to a completely different conception of the kingdom of Erechtheus in the fourteenth century B.c. from that conveyed by the fragmentary remains of the walls of his palace, which have been discovered on the Acropolis, and the unimportant part played by Athens in the Trojan War five generations later as recorded in the Homeric poems.

\section{Industry and Agriculture in Belgium}

Is a pamphlet on the National Foundation for Scientific Research and Industry, the contribution of this body to industry and agriculture in Belgium during the last ten years is reviewed by $P$. Beghin, the secretary of the Foundation (Pp. ix +408 . Bruxelles : Fonds National do la Recherche scientifique). Since the Foundation gave its first grant in July 1928, 252 persons have recoived grants, 75 of whom aro still receiving them, whilo 35 fresh grants aro mado each year. In subsidies of all kinds, 25,000,000 francs has been distributed amongst 1,350 research workers. The annual budget of the Department of Industrial Science of the Foundation is limited to $1,000,000$ francs. Taken by industries, the distribution of research effort is concentrated mainly in agriculture and horticulturo $(1,532,460$ francs $)$ metallurgy $(1,299,000$ francs $)$, electrical engineering $(1,209,400$ francs), out of a total of 7,166,810 francs, chemistry coming next with 730,750 francs and civil engineering with 630,100 francs. The report includes moro or less detailed accounts of work in progress in metallurgy, welding, the thermodynamics of heavy-oil motors, electrical apparatus, including incandescent electric lamps, radio reception, civil engineering, including the action of wind on buildings, chemistry, including synthetic lubricating oils, copal gum, synthetic resins for the electrical industry, vulcanization of rubber, the charcoal industry, glass industry, cement industry, optical industry, as well as in agriculture, including the disinfection of plants and the cultivation of the beetroot, the brewing industry and the tanning of leather.

\section{British Museum (Natural History): Recent Acquisitions}

AN interesting acquisition in the Department of Zoology is a series of the golden mole, Eremitalpa granti, presented by Captain G. C. Shortridge of the Kaffrarian IJuseum, King William's Town, South Africa. The gift comprises seventeen shins and skulls of this insectivore, and forms a valuable addition to the study collections. Mr. F. N. Ashcroft has presented to the Department of Minerology a further selection of well-crystallized minerals from forty. seven carefully recorded localities in Switzerland. The Ashcroft collection of Swiss minerals is unrivalled in the excellence of the specimens and the care with which the localities have been recorded. This latest gift brings the number of specimens added to the Museum's collection from this source in the last ten years to a total of 3,654. Another interesting gift comes from the McGregor Nuseum, Kimberley, through Miss M. Wilman, the curator, and consists of three specimens of the doubly refracting Iceland spar found in Cape Province, South Africa. A collection comprising about 4,900 gatherings of plants has been brought back from South America by Mr. A. H. G. Alston, assistant keeper in the 